\title{
Cross-departmental collaboration in strategic sourcing as a catalyst for supplier development: The case of Eskom
}

\begin{tabular}{|c|c|}
\hline \multicolumn{2}{|c|}{$\begin{array}{l}\text { Authors: } \\
\text { Mzoxolo E. Mbiko }^{1} \\
\text { Tatenda Mbara }^{1} \\
\text { Elana Swanepoel }^{1}\end{array}$} \\
\hline \multicolumn{2}{|c|}{$\begin{array}{l}\text { Affiliations: } \\
{ }^{1} \text { Department of Transport } \\
\text { and Supply Chain } \\
\text { Management, University of } \\
\text { Johannesburg, South Africa }\end{array}$} \\
\hline \multicolumn{2}{|c|}{$\begin{array}{l}\text { Corresponding author: } \\
\text { Tatenda Mbara, } \\
\text { tmbara@uj.ac.za }\end{array}$} \\
\hline \multicolumn{2}{|c|}{$\begin{array}{l}\text { Dates: } \\
\text { Received: } 29 \text { Mar. } 2017 \\
\text { Accepted: } 10 \text { Oct. } 2017 \\
\text { Published: } 30 \text { Nov. } 2017\end{array}$} \\
\hline \multicolumn{2}{|c|}{$\begin{array}{l}\text { How to cite this article: } \\
\text { Mbiko, M.E., Mbara, T. \& } \\
\text { Swanepoel, E., 2017, } \\
\text { 'Cross-departmental } \\
\text { collaboration in strategic } \\
\text { sourcing as a catalyst for } \\
\text { supplier development: The } \\
\text { case of Eskom', Acta } \\
\text { Commercii 17(1), a496. } \\
\text { https://doi.org/10.4102/ } \\
\text { ac.v17i1.496 }\end{array}$} \\
\hline \multicolumn{2}{|c|}{$\begin{array}{l}\text { Copyright: } \\
\text { (c) 2017. The Authors. } \\
\text { Licensee: AOSIS. This } \\
\text { is licensed under the } \\
\text { Creative Commons } \\
\text { Attribution License. }\end{array}$} \\
\hline \multicolumn{2}{|l|}{ Read online: } \\
\hline 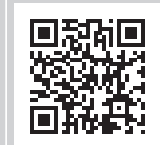 & $\begin{array}{l}\text { Scan this QR } \\
\text { code with your } \\
\text { smart phone or } \\
\text { mobile device } \\
\text { to read online. }\end{array}$ \\
\hline
\end{tabular}

Objective: The objective was to analyse the integration of and collaboration between strategic sourcing and supplier development at Eskom, South Africa's primary electricity supplier, and to determine how strategic sourcing can be a catalyst for supplier development.

Problem investigated: To address fragmented and inefficient procurement, Eskom instituted two departments, Commodity Sourcing (CS), to drive strategic sourcing, and Supplier Development and Localisation (SD\&L), to drive supplier development. The problem is that collaboration between CS and SD\&L has not materialised and thus their mandates have not been entirely achieved.

Research design: A case study research design was employed, drawing from multiple sources of data to triangulate findings. Managers from two departments, CS and SD\&L, were separately surveyed, while face-to-face interviews were conducted with executive management.

Results: The findings revealed a lack of planning, implementation and monitoring of supplier development in the strategic sourcing process of CS. Although the procurement spend in CS is used to drive supplier development objectives, from the perspective of SD\&L, in practice this does not fully materialise.

Originality and/or value of the research: The study is unique as it focuses on crossdepartmental collaboration within the organisation, rather than collaboration across the supply chain with external partners. From insights into the dysfunctional relationship between the departments, solutions for increased collaboration and effective supplier development could be suggested.

Conclusion: For strategic sourcing to be a catalyst of supplier development, it is essential that an integrated strategic sourcing operating model incorporating the objectives of both CS and SD\&L be developed.

\section{Introduction and theoretical background Overview of procurement at Eskom}

Eskom Holdings State-Owned-Company (SOC) Ltd (Eskom) is South Africa's primary electricity supplier, entirely owned by the South African government. Eskom's mission is 'to provide sustainable electricity solutions to grow the economy and improve the quality of life of the people in South Africa and in the region' as indicated in their Eskom Corporate Plan (Eskom 2015a:53), supplying $90 \%$ of the electricity used in South Africa and $40 \%$ in the Southern African Development Community (SADC) region. It owns and operates 29 power stations in South Africa with a total nominal electricity generating capacity of 41134 megawatt (MW). Eskom's electricity generating capacity comprises $36441 \mathrm{MW}$ from coal-fired power stations, $1860 \mathrm{MW}$ from nuclear power, 2409 MW from gas-fired power fuelled by diesel, 2724 MW from pumped storage stations, $600 \mathrm{MW}$ from hydro-stations, as well as 100 MW from Sere wind farm (Eskom 2016:7-10, 2017:4-5). Its wide customer base ranges from industrial, mining, commercial, agricultural and residential customers to redistributors (Eskom 2016:14, 2017:5). From 2015 to 2017, its total procurement spend increased from R136 to R178 billion (Eskom 2015b:79, 2017:71). As a SOC, Eskom's public procurement can be a tool for development and transformation, and in particular supplier development.

Although Eskom's five-year corporate plan (2015-2020) focuses on longer term sustainability and growth, its eight-dimension sustainability framework does not include supply chain sustainability 
explicitly (Eskom 2015a:7-8). It is implicitly required to attain sustainability in the eight dimensions of financial, operational, asset creation, revenue and customer, environmental and climate change, human capital, transformation and social sustainability and reputation enhancement. As confirmed by Monczka et al. (2016:11), supply chain management (SCM) pursues strategic responsibilities aligned with the overall mission and strategies of the organisation and have a major impact on its long-term performance.

Until 2007, Eskom used a decentralised procurement system with procurement decisions made at the operational level, which resulted in fragmented and inefficient procurement as opposed to a centralised system where procurement decisions are centralised in one location (Wisner, Tan \& Leong 2012:60). In 2011, the Group Commercial (GC) division was established to centralise procurement and drive transformation through SCM and procurement initiatives (Eskom 2015a:156), according to clearly defined principles. The GC division consists of eight functions: Project Sourcing, Tactical Sourcing, Supply Chain Operations, Primary Energy, Business Enablement, Risk and Governance, Commodity Sourcing (CS) and Supplier Development and Localisation (SD\&L). While CS procures strategic commodities to ensure continued electricity supply, it is also responsible for supplier relationship management. The SD\&L mandate is to:

achieve maximum and sustainable local development impact by utilising Eskom's procurement spend in a manner that allows flexibility within the business in order to accommodate government's local development initiative and policies. (Eskom 2013a:6)

Its objectives include industry transformation, skills development, industrialisation and localisation (develop South African-based suppliers) (Eskom 2013b:23-31).

However, contrary to the principles of the division's formation, the Evaluation of the Procurement Strategy (Eskom 2013c:9) identified a limited integration mainly between the sourcing function and supplier development, a fragmented approach to supplier development, limited focus on cost savings, undefined interface priorities and processes; misaligned performance measures; ineffective end-to-end processes; and fragmented and uncoordinated procedures. Thus, the integration and collaboration between CS and SD\&L had not fully materialised and had an adverse effect on operational excellence in driving supplier development across Eskom and needed further research. SánchezRodríguez (2009:161) supported the need for further research into the relationship between strategic sourcing and supplier development practices. Although these two concepts have been researched, a study on strategic sourcing as a catalyst for supplier development could not be found. In addition, the National Treasury (2015:7) concluded from their Public Sector Supply Chain Management Review that some of the challenges are as follows: (1) multiple policy objectives and sub-optimal public sector SCM regulatory environment; (2) inadequate planning and inefficient performance management; (3) highly prescriptive and complex procedures and operational challenges related to SCM; (4) high cost of procurement and less focus on value for money; (5) misaligned organisational structures; (6) limited SCM capability and high turnover; (7) fraud, corruption and unethical behaviour; and (8) excessive decentralisation of the procurement system.

\section{Supply chain integration and supplier development}

Supply Chain Management is defined by the Council of Supply Chain Management Professionals (CSCMP) as the 'planning and management of all activities involved in sourcing and procurement, conversion and all logistics management activities' (Pienaar \& Vogt 2016:9). Procurement, a component of SCM, is a process that is associated with an organisation's need to procure goods and services required to operate the organisation (Coyle et al. 2013:7-11). Strategic sourcing, however, refers to the 'organised and collaborative approach to leverage targeted spend across business functions with select suppliers that are best suited to create knowledge and value in the customer-supplier interface' (Engel 2004:1).

As part of SCM, the concept 'supplier development', originated by Leenders (1966), emerged as any activity that a buyer undertakes to improve a supplier's performance and capabilities to achieve the buyer's short-term and long-term supply needs (Handfield et al. 2000:37-39), and to achieve, maintain and improve the buying organisation's competitive advantage and effectiveness (Alaez-Aller \& Longas-Garcia 2010; Modi \& Mabert 2007; Rajput \& Bakar 2012:189). It is an integral part and subject of considerable research in SCM ( $\mathrm{Li}$ et al. 2012:353; Mohanty, Gahan \& Choudhury 2014:201). Supplier development activities involve developing suppliers for long-term partnership and relationship enhancement (Shahzad et al. 2016:56).

Because SCM comprises various activities, supply chain integration aims at seamlessly linking relevant business processes, both within and across organisations, to build an effective and efficient supply chain (Chen, Daugherty \& Roath 2009, cited in Ralston et al. 2015:47). For collaboration between two SCM departments, it is necessary to appreciate the mandate of each.

\section{Strategic sourcing}

Strategic sourcing is a comprehensive and complex process. According to Coyle et al. (2013:559), strategic sourcing is guided by five core principles to achieve the desired level of value. These principles are assessing the total value supplier relationship, developing individual commodity category sourcing strategies, evaluating internal requirements and commodity specification, focusing on supplier economics and driving continuous improvement with the supplier. To comply with these principles, strategic sourcing practitioners would not only leverage the purchasing power but also have 
to involve supplier and customer participation in a crossfunctional team to enable implementation and realisation of strategic benefits (Coyle et al. 2013:555). Studies by Boateng (2015) and Ochieng (2014) stress the long-term benefits and importance of integrating strategic sourcing and supplier development. According to Kocabasoglu and Suresh (2006:4), factors that are essential for executing strategic sourcing are status of the purchasing function within the organisation, level of internal coordination of purchasing with other functions, information sharing with key suppliers and development of key suppliers. To accomplish this, a strategic sourcing process can be followed such as the ones described by Coyle et al. (2013:559), Smeltzer, Manship and Rossetti (2003), Engel (2004) and Dolan and Fedele (2004).

According to the Group Commercial Plan, Eskom (2012) adheres to the seven-step strategic sourcing process. It comprises the following: Step 1: Project Planning Kick-off, involving cross-functional teams and signing-off on the project charter by all members. Each member has roles and responsibilities and the commodity manager leads the team; Step 2: Profile Internally and Externally, of the commodity and suppliers; Step 3: Develop Sourcing Strategy - by crossfunctional team; Step 4: Screen Suppliers and Selection Criteria; Step 5: Conduct Auctions and Request for Proposals - ends with suppliers selection for contracting; Step 6: Shape and Negotiate Value Propositions; and Step 7: Implement Agreements. No mention is made of supplier development objectives in any of these steps.

\section{Supplier development}

Supplier development involves 'working collaboratively with critical, strategic and high-potential suppliers to improve capabilities and competitiveness in the areas of cost, quality, time and technology' (Gordon 2014:1). A critical reason for supplier development is to reduce risk in the supply chain by increasing suppliers' capability for continuous improvements (Chavhan, Mahajan \& Sarang 2012:38). In addition, external factors such as globalisation, supply chain risks and sustainability force organisations to embark on supplier development programmes (Gordon 2014:1-2). Factors that contribute to successful supplier development range from long-term commitment to strategic goals, information sharing, trust, effective communication, supplier evaluation and supplier strategic objectives (Li et al. 2012:363; Mohanty et al. 2014:209). While Hales and Arumugam (2012:60) concluded that supplier development requires participation and cooperation from both internal and external stakeholders, Mohanty et al. (2014:209) asserted that effective supplier development essentially depends on supplier relationship management by the buying organisation. All parties should focus on the end results of the supplier development because it can be mutually beneficial for both buyer and supplier (Rajput \& Bakar 2012:189).

There is no universal approach to supplier development (CIPS 2013:2) but any approach should support the organisation strategy. Both Gordon (2014) and Handfield et al. (2000) developed supplier development models consisting of seven steps. Gordon's (2014:3) model comprises the following steps: Step 1: determine the potential need and executive appetite for supplier development; Step 2: identify target suppliers; Step 3: choose supplier development approach; Step 4: form an internal supplier development team; Step 5: identify specific opportunities at individual suppliers to determine supplier development readiness; Step 6: secure commitment from the supplier's senior management; and Step 7: project plan, agreement, launch and monitoring. The model of Handfield et al. (2000:39-41) has similar steps but is slightly different: Step 1: identify critical commodities; Step 2: identify critical suppliers; Step 3: form a cross-functional team; Step 4: meet with supplier's top management; Step 5: identify key projects; Step 6: define details of agreement; and Step 7: monitor status and modify strategies.

Eskom, however, developed a six-step supplier development process to be executed within procurement processes to address SD\&L objectives (Eskom 2013a:32-37).

Step 1: Demand analysis of the internal demand. Opportunities are identified to enable leveraging of the associated spend for supplier development.

Step 2: Supply analysis for each project or commodity grouping and to develop a strategy.

Step 3: Classification of projects and commodity groupings linked to supplier development objectives, such as industrialisation, localisation, skills development, job creation and exempted micro-enterprises development.

Step 4: Strategy development driven by the nature of the project or commodity grouping.

Step 5: Execution and support, a support team creates the tender and contractual documents.

Step 6: Monitoring and reporting involves collection and verification of local development performance information, and Broad-based Black Economic Empowerment (B-BBEE) spend through the consolidation of SD\&L performance.

In the Eskom supplier development process, no mention is made of a cross-functional team. The identification of critical commodities is key because it simplifies the process of choosing suppliers for development. In the Eskom context, supplier development is mainly concentrated on the development of local suppliers by providing sustainable opportunities to establish and develop existing industries. Eskom defines its supplier development based on achievement of the SD\&L objectives such as industrialisation, localisation, creation of employment opportunities and skills development (Eskom 2013a:24). This is often done through the use of procurement spend. The SD\&L plan involves 
42 operational and project spend focus areas to drive industrialisation and localisation, which constitute $89 \%$ of procurement spend. These objectives are similar to supplier diversity goals undertaken in developed economies.

The Eskom SD\&L Plan covered a time frame of six years, starting in the financial year 2011/2012, and renewed every two years until its expiry date in 2016/2017. The SD\&L department consists of three core functions (Eskom 2013a:14-15) as follows:

- Strategy and Planning: This function is responsible for the analysis of local industries and the skills base (capacity and capability) to develop an Eskom-wide supplier development strategy. It also involves guiding target setting through the development of weightings, segmentation of suppliers and ensures cognisance of government and external policy.

- Execution Support: It provides tactical and negotiation support to Eskom buyers through the development of contractual targets and provides local development policy advice to the function suppliers.

- Monitoring and Reporting: The activities of this function involve the collection, verification, managing and analysis of contract data and measure key performance indicators for internal and external reporting.

Sánchez-Rodríguez (2009:163) stated that supplier development implementation has a direct impact on the supplier performance and, therefore, on the sourcing performance. This author furthermore stated that competitive advantage can be strengthened through the combination of strategic sourcing and supplier development processes or practices.

\section{Integration models}

From a literature review of 69 research papers on supply chain collaboration, Hudnurkar, Jakhar and Rathod (2014) identified 28 factors all relating to the collaboration between supply chain partners, and none addressed the internal collaboration required. As supply chain activities need to be internally integrated prior to engaging with external stakeholders, integrating processes, especially in complex and vertically integrated organisations, are seen as a valuable tool to reduce and eliminate functional silos. Wisner et al. (2012:471) proposed an eight-step integration model to integrate processes in an organisation. The model incorporates corporate or divisional strategies, aligns strategies and key processes and assesses performance for continuous improvement. Both internal and external partners are involved. Performance should be monitored jointly on a quarterly and annual basis. Another important model is that of the McKinsey 7S model, which focuses on the alignment of strategy, structure, systems, style, staff, skills and shared values to allow organisations to achieve strategic objectives (Bartone \& Wells 2009:2-12; Jurevicius 2003). Nevertheless, there are inherent challenges associated with the integration models of processes or functions (Wisner et al. 2012:482), such as a silo mentality, lack of process visibility and information, lack of trust (in a team) and lack of knowledge.

\section{Problem statement and objective}

The problem was that the integration of two supply chain functions, such as CS and SD\&L, to jointly deliver on supplier development inherently has collaborative and other challenges. The primary objective was to assess the collaboration between strategic sourcing and supplier development at Eskom and to determine possibilities for strategic sourcing to be a catalyst for supplier development in the context of Eskom. The study adds new insights into the type of collaborative problems experienced within an organisation when different departments are involved in strategic sourcing and supplier development, and provides possible solutions to delivering on a corporate objective of supplier development, as the latter has been legalised through the Broad-based Black Economic Empowerment (B-BBEE) Act No. 53 of 2003 and the Preferential Procurement Policy Framework Act (PPPFA) No. 5 of 2000, which apply to all South African businesses. Apart from Eskom, this problem could be relevant to both fully and partially owned state enterprises, such as Transnet, Telkom, South African Airways, South African Express, Denel, Safcol and Alexkor (Department of National Treasury 2017:2).

\section{Research methodology}

A case should be selected for specific reasons (Yin 2014:51-52). Eskom was selected as it has the largest procurement spend of all SOCs, and the findings about the collaboration between the two departments could be both critical and revelatory. To gain insights into the relationship between the two departments, an exploratory research design was adopted (Wagner, Kawulich \& Garner 2012:21), incorporating a pragmatic world view to find solutions to a real-life challenge (Creswell 2014) in this cross-sectional study (Cooper \& Schindler 2014:128). According to Yin (2014:106), case study research involves multiple sources of evidence, including documentation, interviews (which were conducted with managers) and other sources. Yin (2014:66) stated that surveys may be embedded within case study research 'to collect data about embedded unit(s) of analysis'. Thus, both a quantitative survey using a semi-structured questionnaire and a qualitative interview schedule were used to collect data (Saunders, Lewis \& Thornhill 2012) from the two departments which are embedded cases in a single case study (Yin 2014:53).

For the survey, the population included all the middle managers in the two departments, CS (24 Commodity Managers) and SD\&L (19 Middle Managers) (Eskom 2015c), directly responsible for the management of strategic sourcing and supplier development, respectively, in Eskom and with the knowledge to provide strategic insights. All the managers from both the departments (total 43) were included in the survey; thus, sampling did not occur. For the qualitative interviews, by means of purposive sampling, the executive 
management comprising the two general managers (each department had one) and eight senior managers (each department had four), a total of 10, comprised the sample. Secondary data sources included Eskom's corporate plan, annual reports, integrated reports, GC reports, Eskom's strategic sourcing and supplier development documentation and National Treasury publications.

For the survey, two semi-structured questionnaires were developed, one for CS commodity managers and one for SD\&L middle managers as the questions had to be adapted to the nature of their tasks. At the end of 2015, the first section of the questionnaire collected demographic data while the second section focused on perceptions pertaining to four topics: current state of strategic sourcing and supplier development at Eskom; role of strategic sourcing and supplier development in Eskom; collaboration between CS and SD\&L; and processes, systems and practices in Eskom. The quantitative survey data were analysed using descriptive statistics. The qualitative interviews were digitally recorded, supplemented with handwritten notes. The qualitative data were coded, categorised and themed (Dudovskiy 2013:48). As the researcher was an Eskom employee, his views and perceptions were carefully bracketed. Eskom has provided permission for this research to be published. The findings were triangulated to converge into meaningful conclusions.

\section{Findings \\ Profiles of survey respondents and interview participants}

\section{Survey respondents}

Of the 43 middle managers, $60 \%$ (26) responded to the survey: 10 from commodity managers in CS and 16 from middle managers in SD\&L. Of the 10 CS commodity managers, seven were men with ages between 30 and 49 years and three were women and were older. On average, each had 15 years of experience in Eskom, and 6 years in managing strategic sourcing in Eskom. They all (except one who did not respond) had degrees, three with undergraduate degree, three with honours degree and three with master's degree. The qualifications ranged from economics, informatics, engineering and logistics to accounting. Such qualifications are relevant to undertake research, economic analysis, understanding the commodity manufacturing process and calculations in procurement and strategic sourcing. In addition, all except one had attended internal training courses related to procurement and strategic sourcing. The following training programmes had been attended: strategic sourcing (7-Step Strategic Sourcing Process), procurement in Eskom, contract management, negotiation, and foreign exchange.

Of the 16 SD\&L middle managers, 13 were men and three were women; 12 respondents were between the ages of 30 and 49 years and 4 were older. On average, each had 13 years of experience in Eskom, and 6 years internal supplier development experience in Eskom. They all had degrees, six with undergraduate degree, two with honours degree and eight with master's degree. The qualifications ranged from statistics, engineering, law, business administration, business leadership, economics, accounting and even counselling psychology. In addition, only nine managers had attended internal training courses related to supplier development. The following training programmes had been attended: enterprise development, strategic sourcing, B-BBEE, supplier development, local content and New Engineering Contract.

\section{Interview participants}

Of the 10 executive managers, nine were interviewed face-toface, consisting of one general manager and eight senior managers; of the interviewees, six were men and three were women; two were in the 30-49 age bracket, while seven were in the 50-59 age bracket; their years of experience at Eskom ranged between 9 and 32 years.

\section{Perceptions about collaboration between commodity sourcing and supplier development and localisation}

All the CS respondents (10) indicated that they use the 7-Step Strategic Sourcing Process in their department, while all the SD\&L respondents (16) indicated that their objectives are normally achieved through leveraging procurement spend on commodities. This is done by setting targets in view of the complexity, value and the duration of the contract. SD\&L is seen as a support function to buyers in the CS. One respondent stated that SD\&L is still in its infancy within Eskom and has not been fully embraced.

To ascertain the CS perspective on SD\&L, questions with 'yes/no' responses revealed the following. Seven of the $10 \mathrm{CS}$ respondents stated that the strategic sourcing process is aligned to the SD\&L programme. The three who disagreed identified the following misalignment: inefficient crossfunctional teams, inefficient monitoring of meeting SD\&L targets, lack of interventions for suppliers who do not meet targets and lack of mechanism to balance cost effectiveness and localisation drive. Although all 10 CS respondents affirmed that the sourcing strategy incorporates SD\&L objectives, the Eskom 7-Step Strategic Sourcing Process used by CS does not include SD\&L objectives in any of its steps. In addition, all the CS respondents affirmed that consultation with SD\&L is always done when developing a sourcing strategy. One CS respondent summarised it as follows:

'SD\&L programmes can be achieved through strategic sourcing, tactical sourcing and project sourcing within Eskom. Whether strategic sourcing is aligned to SD\&L programme or not, it depends on initiatives and ambitions of cross-functional team which is led by the commodity manager to advance localisation, skills development, job creation, industrialisation and support business owned by previously disadvantaged groups. The shortterm (annual objectives) goals of SD\&L must be emphasised and monitored from the beginning of each financial year. Its longterm objectives must as well be made clear to all departments within the organisation and be supported by all Group Executives.' (Participant 5, Male, Manager) 
As SD\&L is implemented within CS procurement processes, the relationship as perceived by SD\&L middle managers was explored. With regard to alignment to CS processes, the SD\&L respondents' views were divided (Table 1: 8/8), in contrast to the CS respondents who were more positive $(7 / 3)$ about the alignment between the two departments. Although 11 SD\&L respondents affirmed that SD\&L objectives are incorporated in the CS strategic sourcing process, five respondents did not. While 10 SD\&L respondents confirmed that they always consult with CS in driving SD\&L objectives, six respondents denied this. In contrast, CS respondents all affirmed that they always consult with SD\&L. Ten SD\&L respondents confirmed the existence of a policy that governs consultation with other functions; however, six respondents denied the existence of such a policy. Of the CS respondents, eight confirmed the existence of such a policy. The existing policy referred to by the respondents could be the authorised Eskom Procurement and Supply Management Procedures which may be confused with a consultation policy, explaining the differences in responses. In summary, the SD\&L respondents are less positive about the collaboration with CS, than vice versa.

\section{Perceptions of each other's roles in the cross-functional teams}

In response to an open-ended question, CS respondents identified several roles of SD\&L in the cross-functional team. One of the main roles is to guide the cross-functional team to understand the SD\&L mandate and how CS can contribute to the achievement of SD\&L objectives by ensuring that they are incorporated in sourcing strategies. SD\&L should identify opportunities of advancing elements of SD\&L for each commodity, to develop industries, suppliers and build capacity in terms of scarce skills. As part of the crossfunctional team, they need to be involved from the initial stages of the process to obtain an understanding of the commodity and the markets and the industry of the commodity in order to influence the strategy for the various commodities and the selection of suppliers. In addition, they should be monitoring post-contract awards. To accomplish this requires trained sourcing specialists.

A similar question was posed to the SD\&L middle managers to identify the roles of the CS commodity managers in crossfunctional teams. The SD\&L respondents indicated that CS

TABLE 1: Supplier Development and Localisation respondents' perceptions of the relationship with Commodity Sourcing.

\begin{tabular}{|c|c|c|c|c|}
\hline \multirow[t]{2}{*}{ Question } & \multicolumn{2}{|c|}{ Yes } & \multicolumn{2}{|c|}{ No } \\
\hline & $n$ & $\%$ & $n$ & $\%$ \\
\hline Is SD\&L aligned to CS processes? & 8 & 50 & 8 & 50 \\
\hline $\begin{array}{l}\text { Are SD\&L objectives incorporated in the strategic } \\
\text { sourcing process in CS? }\end{array}$ & 11 & 69 & 5 & 31 \\
\hline $\begin{array}{l}\text { Do you always consult with CS in driving SD\&L } \\
\text { objectives? }\end{array}$ & 10 & 63 & 6 & 38 \\
\hline $\begin{array}{l}\text { Is there a policy that governs the consultation with } \\
\text { other functions in pursuing SD\&L? }\end{array}$ & 10 & 63 & 6 & 38 \\
\hline
\end{tabular}

should lead the cross-functional team and ensure proper alignment of all business objectives including those of SD\&L. Three SD\&L respondents reiterated that CS should drive the sourcing process and coordinate the inputs from crossfunctional team members into a sourcing contract with an SD\&L agenda. In addition, they advised that CS needs to consult with other business functions to understand their needs for effective and efficient sourcing of commodities; CS should adhere to all the steps of the strategic sourcing process and all members of the cross-functional team should be involved in the entire process, and not just someone from CS.

With regard to collaboration and consultation, the SD\&L respondents stated that CS should collaborate with SD\&L and develop procurement plans that incorporate SD\&L requirements. In addition, CS discussions on cost effectiveness, quality, timeliness and sustainability of sourcing products and services should take into consideration SD\&L's objectives. Furthermore, CS should proactively inform SD\&L about any planned procurement transactions and collaborate with SD\&L to incorporate developmental objectives in all formal CS transactions. From the suggestions of both the CS and SD\&L respondents, it seems that roles and interdependency between CS and SD\&L in the crossfunctional team need clarification.

\section{Executive management insight into the relationship between Commodity Sourcing and Supplier Development and Localisation}

From the interviews with the nine executive managers, insight into the misalignment between CS and SD\&L was obtained. Seven executive participants explained that when the 7-Step Strategic Sourcing Process was developed, it did not include SD\&L and the latter can be considered a 'retrofit' (said one participant). Some participants affirmed that SD\&L was created as a supporting function rather than a strategic activity at Eskom. One participant suggested that the misalignment is triggered by the structural and fragmented approach to strategic decision-making, while another participant ascribed it to 'disjointed coordination', and yet another one said that it emanated from the lack of role clarity and ownership or limited resource capabilities in the organisation. It seems that even though the executives are aware of the misalignment between CS and SD\&L, multiple factors could be contributing to the situation. Nevertheless, the outcome is the sub-optimal treatment of the 42 focus areas in CS and the non-strategic positioning of SD\&L as a target setting function. To remedy this relationship, six participants suggested a review of the 7-Step Strategic Sourcing Process to reflect inclusivity of SD\&L or to merge the two departments or capacitate commodity managers to carry out the SD\&L mandate and be measured through performance contracts.

\section{Strategic sourcing as a catalyst for supplier development in Eskom}

To assess whether strategic sourcing can be a catalyst for effective supplier development in Eskom, 10 questions using 
a five-point Likert scale (from strongly disagree to strongly agree) were used. Similar questions, adapted to the context of each department, were completed by both the CS and SD\&L respondents (Table 2).

The CS and SD\&L perceptions illustrated in Table 2 are clarified as follows:

- Although $60 \%$ of CS respondents agreed and strongly agreed that CS is thoroughly integrated with SD\&L, only $25 \%$ of SD\&L respondents agreed and strongly agreed that SD\&L sourcing is thoroughly integrated with CS, while $44 \%$ disagreed and $31 \%$ ventured no opinion. Thus, a serious difference in the perception of the extent of integration between the two departments exists.

- With regard to the proactive and coherent management of integration between the two departments, half (50\%) of the CS respondents strongly disagreed and disagreed, while a further $40 \%$ refrained from providing an opinion. Of the SD\&L respondents, a larger percentage $(60 \%)$ disagreed that integration is managed proactively.

- In spite of this fact, 70\% of the CS respondents agreed and strongly agreed that a collaborative framework exists between CS and SD\&L, although only $31 \%$ of the SD\&L respondents agreed with this statement and half were neutral. Again, a serious difference in perceptions exists between the two departments.

- Of the CS respondents, $60 \%$ agreed and strongly agreed that the existing organisational culture promotes collaboration between CS and SD\&L, while $50 \%$ of the SD\&L respondents disagreed and $31 \%$ were neutral. The difference in perceptions between the two departments is pronounced.
- $\quad$ The CS respondents (70\%) agree and strongly agree that leadership is supportive in both departments, while only $44 \%$ of the SD\&L respondents perceive it as such and $38 \%$ disagree.

- On the issue of jointly developing strategic objectives for the financial year, both CS (40\% disagree and strongly disagree with $40 \%$ neutral) and SD\&L (50\% disagree with $44 \%$ neutral) respondents disagree. Thus, there does not seem to be joint developing of strategic objectives.

- Regarding jointly monitoring and evaluating objectives, half of the CS respondents (50\%) either disagreed or strongly disagreed with $30 \%$ neutral, while $57 \%$ of the SD\&L respondents either disagreed or strongly disagreed with $38 \%$ neutral. Thus, no joint monitoring takes place.

- Most (90\%) of the CS respondents agreed and strongly agreed that the objectives of SD\&Lare always incorporated in CS strategic sourcing process, while only $44 \%$ of the SD\&L respondents agreed with this statement and 32\% disagreed and strongly disagreed.

- Respondents from both departments view each other as a critical member of the cross-functional team (both agreed and strongly agreed: $100 \%$ of CS respondents and $82 \%$ of SD\&L respondents).

- Neither the SD\&L processes seem to be well understood by CS respondents ( $40 \%$ agreed and strongly agreed to understanding while 30\% abstained and 30\% disagreed and strongly disagreed), nor are the CS strategic sourcing process well understood by the SD\&L respondents $(25 \%$ agreed, 31\% were neutral and $44 \%$ disagreed and strongly disagreed).

TABLE 2: Perceptions of Commodity Sourcing and Supplier Development and Localisation managers regarding strategic sourcing as a catalyst.

\begin{tabular}{|c|c|c|c|c|c|}
\hline Statement & Strongly disagree $\% \dagger$ & Disagree $\% \dagger$ & Neutral \%† & Agree $\% \dagger$ & Strongly agree $\% \dagger$ \\
\hline \multicolumn{6}{|l|}{ Perceptions of the CS commodity managers $(n=10)$} \\
\hline Commodity sourcing is thoroughly integrated with SD\&L & 10 & 20 & 10 & 50 & 10 \\
\hline Integration between CS and SD\&L is managed proactively and coherently & 10 & 40 & 40 & 0 & 10 \\
\hline A collaborative framework exists between CS and SD\&L & 0 & 30 & 0 & 60 & 10 \\
\hline Existing organisational culture promotes collaboration between CS and SD\&L & 0 & 30 & 10 & 50 & 10 \\
\hline Leadership is supportive of both departments & 0 & 10 & 20 & 50 & 20 \\
\hline CS and SD\&L jointly develop strategic objectives for the financial year & 10 & 30 & 40 & 20 & 0 \\
\hline Monitoring and evaluation of objectives is done jointly with the SD\&L & 10 & 40 & 30 & 10 & 10 \\
\hline SD\&L objectives are always incorporated in CS strategic sourcing process & 0 & 0 & 10 & 50 & 40 \\
\hline SD\&L is viewed as a critical member of a cross-functional team & 0 & 0 & 0 & 60 & 40 \\
\hline SD\&L processes are well understood in CS & 10 & 20 & 30 & 30 & 10 \\
\hline \multicolumn{6}{|l|}{ Perceptions of the SD\&L middle managers $(n=16)$} \\
\hline SD\&L sourcing is thoroughly integrated with CS & 0 & 44 & 31 & 19 & 6 \\
\hline Integration between SD\&L and CS is managed proactively and coherently & 0 & 60 & 13 & 27 & 0 \\
\hline Existing organisational culture promotes collaboration between SD\&L and CS & 0 & 50 & 31 & 19 & 0 \\
\hline Leadership is supportive of both departments & 0 & 38 & 19 & 37 & 6 \\
\hline SD\&L and CS jointly develop strategic objectives for the financial year & 0 & 50 & 44 & 6 & 0 \\
\hline Monitoring and evaluation of objectives is done jointly with the CS & 13 & 44 & 37 & 6 & 0 \\
\hline SD\&L objectives are always incorporated in CS strategic sourcing process & 12 & 19 & 25 & 44 & 0 \\
\hline CS is viewed as a critical member of a cross-functional team & 6 & 6 & 6 & 57 & 25 \\
\hline CS strategic sourcing process is well understood in SD\&L & 13 & 31 & 31 & 25 & 0 \\
\hline
\end{tabular}




\section{Ethical considerations}

Ethical clearance was sought and given by the University of Johannesburg.

\section{Discussion}

From these findings on collaboration between the two departments, it follows that the perceptions of the SD\&L respondents are distinctly more negative, while those of the CS respondents are more positive. Taking into consideration these differences, it was necessary to assess whether effective integration between strategic sourcing and supplier development could be a possibility. All the CS and SD\&L respondents affirmed that the 'strategic sourcing process in CS is a platform that can be used to advance SD\&L objectives in Eskom'. However, they were divided on the issue of whether 'SD\&L processes are appropriately incorporated in strategic sourcing process', with only $52 \%$ stating 'yes'. Thus, for strategic sourcing to be a platform for the advancement of SD\&L, it would require the systematic incorporation of SD\&L processes into the strategic sourcing process as outlined in the section 'Perceptions of each other's roles in the crossfunctional teams'. In summary, CS should devise procurement plans that incorporate SD\&L development objectives in all formal CS transactions. This topic is expanded upon in the next paragraphs.

The possibility of the CS strategic sourcing process serving as a platform to advance SD\&L objectives in Eskom was verified with the nine executive management participants who suggested the following. Firstly, SD\&L must be accepted as obligatory, requiring a change in the mindset in the entire supply chain to support development. In particular, it would require a review of the 7-Step Strategic Sourcing Process to integrate SD\&L at an early stage. A consolidation of sourcing functions should be considered and this would involve a possible restructuring of the CS and SD\&L departments within GC to improve communication and accountability across the business functions. Furthermore, commodity managers should be empowered to drive SD\&L objectives in sourcing. It was stated that as strategic sourcing is a powerful instrument to address multiple objectives, support from the Chief Executive Office and the Executive Committee to champion strategic sourcing and supplier development is essential.

Whether the CS and SD\&L respondents were in agreement about integration and collaboration between the two departments had to be assessed. The majority of respondents $(85 \%)$ affirmed that there is a need for a joint strategic planning committee between CS and SD\&L, particularly because currently open and effective communication does not seem to exist between CS and SD\&L (46\% stated 'no' and $54 \%$ stated 'yes'), and respondents were divided (50\%) on the existence of close collaboration between CS and SD\&L. It seems that currently performance measurement of CS and SD\&L is not done jointly, as $85 \%$ responded 'no'. Open and effective communication is an integral part of any collaborative initiative in business. All the executive manager participants supported the establishment of the joint strategic planning committee. These findings align with Mathuramaytha's (2011:106) theoretical model of supply chain collaboration (SCC), which identified three critical dimensions: information sharing, decision synchronisation and incentive alignment.

To remedy the current situation, CS and SD\&L respondents were asked to suggest processes, systems or practices required for effective integration of CS and SD\&L (open question). They suggested that every business function should have and report on SD\&L performance metrics, that CS be compacted on SD\&L performance, that SD\&L practitioners be placed within the CS department, that a well-coordinated and integrated procurement strategy be developed and that the business plan and measurements be properly implemented. The executive manager participants suggested that strategic sourcing practitioners need to be skilled appropriately; a change management programme should address behavioural factors; there should be a timely development of the sourcing strategy; and a disciplined organisation should be created not only in theory but also in practice.

From the responses, it was found that CS respondents are generally comfortable with the strategic sourcing processes, which include limited integration of SD\&L objectives. On the contrary, SD\&L respondents appeared to be discontent with the lack of integration, while CS respondents are frustrated with the invisibility of the SD\&L representation in crossfunctional teams.

\section{Conclusions}

The objective of this study was to determine whether strategic sourcing can be a catalyst for effective supplier development in Eskom. There seems to be a mutual understanding between CS and SD\&L that strategic sourcing is a powerful mechanism to advance supplier development in Eskom. Strategic sourcing has the potential to achieve multiple objectives rather than merely sourcing a product or service. It can drive industrialisation, economic development, cost savings, innovation and supplier relationships. Both Yavas et al. (2011:04) and Rajput and Bakar (2012:189) supported this view and stated that strategic sourcing can be a well-placed source of competitive advantage and can achieve, maintain and improve the buying organisation's competitive advantage.

A number of challenges which inhibit integration were identified by respondents and participants: (1) unplanned integration which lacks strategic consideration, (2) presence of structural misalignment and fragmented approach between CS and SD\&L, (3) ineffective cross-functional teams, (4) exclusion of SD\&L objectives in the 7-Step Strategic Sourcing Process, (5) undefined roles and incompatibility between CS and SD\&L, (6) disregard of SD\&L as a strategic function for Eskom and (7) the lack of interdependent 
processes between the two departments. There also seems to be a lack of a clear framework of how supplier development is designed to effectively leverage procurement for the achievement of organisational objectives.

Four actions (themes) emerged for the collaboration and integration between CS and SD\&L to enable strategic sourcing to serve as a catalyst for supplier development: (1) establish open and effective communication between CS and SD\&L, (2) institute joint performance measurements, (3) ensure close collaboration between CS \& SD\&L and (4) create a joint strategic sourcing planning committee. These themes are supported by the golden rules for strategic sourcing identified by Kocabasoglu and Suresh (2006:4): let prior implementation determine the status of the purchasing function within the organisation, improve the level of internal coordination of purchasing with other functions, promote information sharing with key suppliers and integrate the development of key suppliers. The establishment of the joint planning committee and ensuring joint performance measurement between CS and SD\&L to strengthen integration should be prioritised. An integration model, such as the one proposed by Wisner et al. (2012:471), can be used.

The study is unique as it focuses on cross-departmental collaboration within the organisation, rather than collaboration across the supply chain with partners. From insights into the dysfunctional relationship between the departments, solutions for increased collaboration and effective supplier development could be suggested.

\section{Recommendations and managerial implications}

From the findings of this study, it is recommended that, as a first step, a strategy for the integration of supplier development into strategic sourcing be developed, including supplier development in the 7-Step Strategic Sourcing Process. This would require a review of the GC operating model and the alignment of the CS and SD\&L business processes, including the constitution of the members of the cross-functional team with clear roles and responsibilities allocated. As part of monitoring and evaluation of implementation of supplier development, it should be included in the performance management of departments. From these findings, it is further recommended that, to comply with B-BBEE and PPPFA, all SOCs and the corporate sector with either similar challenges or intending to set up cognate structures focus on the integration of strategic sourcing and supplier development instead of allowing them to function separately.

\section{Future research}

Further research should focus on the development of frameworks or departmental integration models to optimise procurement spend while simultaneously complying with supplier development in accordance with B-BBEE and PPPFA.

\section{Acknowledgements}

The authors wish to thank the Eskom Management for allowing the study to be conducted and results published.

\section{Competing interests}

The authors declare that they have no financial or personal relationships that may have inappropriately influenced them in writing this article.

\section{Authors' contributions}

M.E.M. conducted the research under the supervision of T.M. and E.S. The article was drafted by E.S with inputs from the other two authors.

\section{References}

Alaez-Aller, R. \& Longas-Garcia, J.C., 2010, 'Dynamic supplier management in the automotive industry', International Journal of Operations \& Production Management 30(3), 312-335. https://doi.org/10.1108/01443571011024647

Bartone, T.B. \& Wells, L. II, 2009, Understanding and leading Porous Network organisations: An analysis based on the $7 \mathrm{~S}$ model, Centre for Technology and National Security Policy, National Defense University, viewed 08 July 2016, from http://www.dtic.mil/FFB68938-4EBC-4039-BEEC-DD3E84E4F57A/ http://Ww w.dtic.mil/FFB68938-4E BC-4039-BEEC-DD3E84E4F57A/ FinalDownload/Dowoadld-4996EB74FFB6CC99E7CF6088303E0031/

Boateng, D., 2015, Executive insights into strategic sourcing, Boateng, Johannesburg, South Africa.

Broad-Based Black Economic Empowerment (B-BBEE Act No. 53 of 2003), Government Gazette, Republic of South Africa, Volume 463, 9 January 2004, No. 25899.

Chavhan, R., Mahajan, S.K. \& Sarang, J.P., 2012, 'Supplier development: Theories and practices', Journal of Mechanical and Civil Engineering 3(3), 37-51. https://doi. org/10.9790/1684-0333751

Chen, H., Daugherty, P.J. \& Roath, A.S., 2009, 'Defining and operationalising supply chain process integration', Journal of Business Logistics 30(1), 63-84. https://doi. org/10.1002/j.2158-1592.2009.tb00099.x

Chartered Institute of Procurement and Supply (CIPS), 2013, Purchasing and supply chain management: Supplier development. Supplier development - CIPS positions on practice, Stamford, United Kingdom, viewed 26 August 2015, from https:// www.cips.org/Documents/Knowledge/Procurement-Topics-and-Skills/5Strategy-and-Policy/Procurement-Policy-Development/POP-Supplier. Development.pdf

Cooper, D.R. \& Schindler, P.S., 2014, Business research methods, 12th edn., McGrawHill Education, New York.

Coyle, J.J., Langley, C.J., Jr., Novack, R.A. \& Gibson, B.J., 2013, Managing supply chains: A logistics approach, 9th edn., South-Western, Cengage Learning, Ontario, Canada.

Creswell, J.W., 2014, Research design: Qualitative, quantitative and mixed methods approaches, 4th edn., Sage, London, United Kingdom.

Department of National Treasury, 2017, Public institutions listed in PFMA schedule 1, 2, 3a, 3b, 3c and $3 d$ as at 24 February 2017, viewed 30 September 2017, from http://www.treasury.gov.za/legislation/pfma/public\%20entities/2017-02-24\%20 Public\%20institutions\%20Sch\%201-3D.pdf

Dolan, T. \& Fedele, K.M., 2004, 'Strategic sourcing: Reducing cost and supporting diversity goals', in 89th Annual International Supply Management Conference, April, viewed 26 August 2015, from https://www.instituteforsupplymanagement. org/files/Pubs/Proceedings/GFDolanFedele.pdf.

Dudovskiy, J., 2013, An ultimate guide to writing a dissertation in business studies: A step-by-step assistance, viewed 26 August 2015, from http://researchmethodology.net/about-us/ebook/.

Engel, R.J., 2004, 'Strategic sourcing: A step-by-step practical model', in 89th Annual International Supply Management Conference, April, The Procurement Centre, USA, viewed 12 August 2015, from https://www.instituteforsupplymanagement org/files/pubs/proceedings/fbengel.pdf

Eskom, 2012, Group commercial business plan 2012/2013-2016/2017, Eskom, Sunninghill, South Africa.

Eskom, 2013a, Supplier development and localisation presentation, Eskom, Sunninghill, South Africa.

Eskom, 2013b, Eskom supplier development and localisation plan 2013/2015, Eskom, Sunninghill, South Africa.

Eskom, 2013c, Evaluation of procurement strategy, Eskom, Sunninghill, South Africa.

Eskom, 2015a, Corporate plan 2015/16-2019/20. Revision 3, Unique identifier 24056927206 , Sunninghill, South Africa.

Eskom, 2015b, Integrated report, Eskom, Sunninghill, South Africa. 
Eskom, 2015c, Commodity sourcing and supplier development and localisation, Eskom, Sunninghill, South Africa.

Eskom, 2016, Integrated report, Eskom, Sunninghill, South Africa.

Eskom, 2017, Integrated report, Eskom, Sunninghill, South Africa.

Gordon, S., 2014, Supplier development to gain a competitive edge, Bravo Solution, Chicago, IL.

Hales, M. \& Arumugam, R., 2012, 'The case for supplier development', Supply Chain Management Review, viewed 27 August 2015, from https://www. atkearney.com/documents/10192/178350/SCMRSupplierDevolopment. pdf/2fc83a86-127a-478e-ad08-1cc9a9a56acb

Handfield, R.B., Krause, D.R., Scannell, T.V. \& Monczka, R.M., 2000, 'Avoiding the pitfalls in supplier development', Sloan Management Review 41(2), 37-50.

Hudnurkar, M., Jakhar, S. \& Rathod, U., 2014, 'Factors affecting collaboration in supply chain: A literature review', Procedia - Social and Behavioral Sciences 133 189-202. https://doi.org/10.1016/j.sbspro.2014.04.184

Jurevicius, O., 2003, 'McKinsey 7S model', Strategic Management Insight, viewed 08 July 2016, from https://www.strategicmanagementinsight.com/tools/mckinsey7s-model-framework.html

Kocabasoglu, C. \& Suresh, N.C., 2006, 'Strategic sourcing: An empirical investigation of the concept and its practices in the U.S. manufacturing firms', Journal of Supply Chain Management 42(2), 4-16. https://doi.org/10.1111/j.1745-493X 2006.00008.x

Leenders, M.R., 1966, 'Supplier development', Journal of Purchasing 2(4), 47-62. https://doi.org/10.1111/j.1745-493X.1966.tb00039.x

Li, W., Humphreys, P.K., Yeung, A.C.L. \& Cheng, T.C.E., 2012, 'The impact of supplie development on buyer competitive advantage: A path analytic model', International Journal of Production Economics 135, 353-366. https://doi org/10.1016/j.ijpe.2011.06.019

Mathuramaytha, C., 2011, 'Supply chain collaboration: What's an outcome?: A theoretical model', in International Conference on Financial Management and Economics, IPEDR, 11 (2011), IACSIT Press, Singapore, 02-03 July 2011 pp. 102-108.

Modi, S.B. \& Mabert, V.A., 2007, 'Supplier development: Improving supplier development through knowledge transfer', Journal of Operations Management 25(1), 42-64.

Mohanty, M.J., Gahan, P. \& Choudhury, S., 2014, 'Why most of the supplier development programs fail in discrete manufacturing - Finding from selected Indian discrete manufacturing industries', International Journal of Managemen Science and Engineering Management 9(3), 201-211. https://doi.org/10.1080/17 509653.2014.884454
Monczka, R.M., Handfield, R.B., Giunipero, L.C. \& Patterson, J.L., 2016, Purchasing and supply chain management, 6th edn., South-Western Cengage Learning, Boston, MA.

National Treasury, 2015, Public sector supply chain management review, Department: National Treasury, Pretoria, South Africa.

Ochieng, V., 2014, 'Role of supplier development in effectiveness of procurement function: A case of National Cereal and Produce Board', International Research Journal of Business and Management III, 49-62.

Pienaar, J.W. \& Vogt, J.J. 2016, Business logistics management: A value chain perspective, Oxford University Press, Cape Town, South Africa.

Preferential Procurement Policy Framework Act (PPPFA) No. 5 of 2000, Republic of South Africa, 2 February 2000

Rajput, A. \& Bakar, A.H.A., 2012, 'Elements, benefits and issues of supplier development contextualising multiple industries', Journal of Basic and Applied Scientific Research 2(11), 11186-11195.

Ralston, P.M., Blackhurst, J., Cantor, D.E. \& Crum, M.R., 2015, 'A structure-conductperformance perspective of how strategic supply chain integration affects firm performance' Journal of Supply Chain Management 51(2), 47-64. https://dol. org/10.1111/jscm.12064

Sánchez-Rodríguez, C., 2009, 'Effect of strategic purchasing on supplier development and performance: A structural model', Journal of Business \& Industrial Marketing 24(3/4), 161-172. https://doi.org/10.1108/08858620910939714

Saunders, M., Lewis, P. \& Thornhill, A., 2012, Research methods for business students, 6th edn., Pearson Education Limited, London.

Shahzad, K., Sillanpää, I., Sillanpää, E. \& Imeri, S., 2016, 'Benchmarking supplier development: An empirical case study of validating a framework to improve buyer-supplier relationship', Management and Production Engineering Review 7(1), 56-70. https://doi.org/10.1515/mper-2016-0007

Smeltzer, L.R., Manship, J.A. \& Rossetti, C.L., 2003, 'An analysis of the integration of strategic sourcing and negotiation planning', Journal of Supply Chain Management 39(4), 16-25. https://doi.org/10.1111/j.1745-493X.2003.tb00161.X

Wagner, C., Kawulich, B. \& Garner, M. (eds.), 2012, Doing social research: A global context, McGraw-Hill, London.

Wisner, J.D., Tan, K. \& Leong, G.K., 2012, Supply chain management: A balanced approach, 3rd edn., South-Western Cengage Learning, Ontario.

Yavas, B.F., Leong, G.K., Vardiabasis, D. \& Christodoulidou, N., 2011, 'Strategic sourcing: A comparative study across two industries', International Journal of Business and Management 6(4), 3-15. https://doi.org/10.5539/ijbm.v6n4p3

Yin, R.K., 2014, Case study research: Design and methods, 5th edn., Sage, Los Angeles, CA. 